\title{
Moodle Sebagai Pembelajaran Dalam Sekolah Menengah Atas
}

\author{
Harry Dhika, Fitriana Destiawati, Michael Sonny, Surajiyo \\ Universitas Indraprasta PGRI, Jakarta \\ Jl. Nangka No. 58C, Tanjung Barat, Jagakarsa - Jakarta Selatan \\ dhikatr@yahoo.com, honeyzone86@gmail.com,michael.sonny@gmail.com, \\ drssurajiyo@yahoo.com
}

\begin{abstract}
Abstrac- Learning methods begin to be less effective because some students do not actively interact with teaching teachers when the learning process takes place and lack of parental supervision. In a centralized learning method like this students are not too required to be independent in learning activities, such as searching for materials and discussion material because everything has been provided by the teacher. Learning Methods E-learning is applied to overcome students' problems in the process of teaching and learning activities in the classroom. Moodle is an application built to support the process of teaching and learning activities by utilizing internet media through a website using the principles of social constructivist pedagogy which will greatly help teachers from all aspects of the teaching and learning process. The research method that will be used is a qualitative descriptive method by using saturated samples where the population is equal to the number of samples. The technique that will be used in the process of collecting data is search and observation. The results of this study are active interactions between students, and also with teachers and parents in the process of teaching and learning activities, forums for discussion between students, and also with teachers. Because e-learning can also be used as a discussion forum, holding online quizzes, and other learning materials, so the learning process will be more flexible and effective for students and lecturers.
\end{abstract}

Keywords: moodle, teacher, students, parents, online learning

Abstrak- Metode pembelajaran mulai kurang efektif karena beberapa siswa tidak terlalu aktif berinteraksi dengan guru pengajar ketika proses pembelajaran berlangsung dan kurangnya pengawasan orang tua. Dalam metode pembelajaran terpusat seperti ini siswa tidak terlalu dituntut untuk mandiri dalam kegiatan belajar, seperti mencari bahan dan bahan diskusi karena semuanya telah disediakan oleh guru. Metode Pembelajaran Elearning diterapkan untuk mengatasi masalah siswa dalam proses kegiatan belajar mengajar di kelas. Moodle merupakan aplikasi yang dibangun untuk mendukung proses kegiatan belajar mengajar dengan memanfaatkan media internet melalui situs web menggunakan prinsip konstruktivis sosial pedagogi yang akan sangat membantu guru dari semua aspek proses belajar mengajar. Metode penelitian yang akan digunakan adalah metode deskriptif kualitatif dengan menggunakan sampel jenuh dimana populasinya sama dengan jumlah sampel. Teknik yang akan digunakan dalam proses pengumpulan data adalah pencarian dan observasi. Hasil penelitian ini adalah interaksi aktif antara siswa, dan juga dengan guru dan orang tua dalam proses kegiatan belajar mengajar, forum untuk diskusi antara siswa, dan juga dengan guru. Karena e-learning juga dapat digunakan sebagai forum diskusi, mengadakan kuis online, dan materi pembelajaran lainnya, sehingga proses pembelajaran akan lebih fleksibel dan efektif bagi siswa dan guru.

Kata kunci: moodle, guru, siswa, orang tua, pembejaran online 


\section{PENDAHULUAN}

Dalam perkembangan dunia pendidikan, sekolah merupakan tempat proses belajar mengajar bagi siswa dan guru. Tidak hanya sekolah, proses belajar mengajar juga memerlukan kurikulum dalam setiap semester. Kurikulum mengalami perubahan dari tahun ke tahun sesuai dengan kebutuhan. Materi pembelajaran diharapkan dapat disajikan dalam bentuk power point, video belajar, modul, dan lain sebagainya yang akan dapat membantu guru dalam menerapkannya didalam proses belajar mengajar. Namun saat ini yang terjadi proses pembelajaran masih terpusat disatu sistem yang dimana siswa hanya mengharapkan materi dari guru. Sistem seperti ini akan membuat siswa menjadi kurang aktif didalam kelas karena keterbatasan waktu yang dimiliki oleh pengajar saat proses pembelajaran. Maka dari itu siswa menjadi kurang mandiri dalam kegiatan pembelajaran karena siswa saat ini dituntut kreatif dan aktif. Melalui sistem e-learning proses kegiatan belajar mengajar yang dilakukan bisa dengan jarak jauh tanpa harus bertatap muka didalam ruang kelas. Karena yang terjadi dalam proses pembelajaran selama ini selalu dilakukan didalam ruangan yang dimana pengajar memberikan materi dengan bertatap muka langsung dengan siswa. Dengan e-learning pengajar dapat memberikan materi menggunakan internet melalui gadget mobile seperti smartphone dan komputer. Pengajar dan siswa hanya memerlukan akses internet atau intranet berbasis LAN maupun WLAN.

Pemanfaatan aplikasi berbasis LCMS (Learning Content Managemen System) Merupakan konsep pembelajaran digital dengan memanfaatkan e-learning. Pengembangan aplikasi LCMS dilakukan dalam berbagai bentuk dan variasi, juga mudah ditemukan di internet. Namun proses penerapan masih sangat jarang didalam aspek pendidikan meskipun ada yang sudah menerapkan sistem ini tapi tidak begitu optimal pemanfaatannya. Moodle dirancang sedemikian rupa sehingga memiliki banyak fitur dan dapat disesuaikan dengan kebutuhan setiap instansi atau partisipan itu sendiri. Aplikasi ini memang dibuat untuk proses kegiatan pembelajaran berbasis internet melalui situs web yang dibangun khusus dan juga menggunakan prinsip sosial constructionist pedagogy yang dimana dapat membantu pengajar dalam proses pembelajaran dari segala aspek. Dengan ini siswa, pengajar bahkan orang tua dapat menuangkan segala pemikirannya dan membantu pengajar dalam memantau setiap siswa. Aktifitas dapat saling berinteraksi satu sama lain bahkan dengan pengajar itu sendiri. Pengajar tidak perlu merubah gaya megajarnya dengan menggunakan aplikasi moodle ini, tapi elearning ini bisa mendukung kegiatan pembelajaran dan perkembangannya akan terus dirancang dan disesuaikan untuk mendukung proses kegiatan pembelajaran pedagogis yang dimana merupakan hal yang paling utama. Moodle menggunakan bahasa pemrograman PHP dan HTML serta memanfaatkan MySQL sehingga dapat digunakan secara bebas. Moodle juga merupakan aplikasi dengan kode sumber terbuka (Opensource) dibawah lisensi GNU maka dari itu dapat dimodifikasi atau didesign ulang dan lain sebagainya. Pengoprasiannya pun dapat menggunakan komputer PC atau Laptop yang sudah terinstal PHP dan Web Server Apache yang didukung terhadap MySQL sebagai databasenya. Aplikasi ini dapat didownload secara bebas di internet karena tidak perlu membayar lisensi apapun untuk 
mendowload aplikasi ini. Moodle dikembangkan oleh seorang pengajar dan analisi teknologi informasi kebangsaan Australia yaitu Martin Dogiamas[1].

Bagi seorang programmer, moodle adalah hal yang asing untuk didengar. Tapi bagi tenaga pengajar istilah moodle adalah hal yang biasa, karena "moodle" dalam bahasa Indonesia adalah modul yang artinya modul pembelajaran, silabus, dan lain sebagainya. Moodle dalam proses pembelajaran diharapkan dapat menumbuhkan kreativitas dan wawasan bagi siswa atau peserta didik. Karena pembelajaran konvensional yang dilakukan secara terpusat terbukti tidak efektif karena jumlah peserta didik yang mungkin lebih banyak di dalam ruangan sehingga materi pembelajaran kurang tersampaikan dengan sempurna karena beberapa faktor yang mungkin berasal dari siswa itu sendiri. Dan juga keterbatasan waktu yang dimiliki oleh pengajar saat proses pembelajaran. Lainnya adalah pendekatan yang dilakukan pengajar kepada siswa yang tidak dapat dilakukan didalam ruangan, jika menerapkan e-learning pegajar bisa berinteraksi langsung dengan siswa tanpa ada batasan waktu dan ruang dalam proses pembelajaran.

Dengan diterapkannya sistem moodle dalam proses belajar mengajar untuk materi pembelejaran disekolah wilayah Yogyakarta ini dapat bermanfaat dalam meningkatkan interaksi pengajar dengan siswa dan siswa dengan orang tuanya. Juga merupakan materi sumber pembelajaran yang tidak terbatas. Apabila dikembangkan dengan procedural dapat menigkatkan kualitas kelulusan dan sekolah itu sendiri. Moodle juga dapat membuat forum diskusi bagi komunitas siswa dan pengajar agar bisa saling berinteraksi, dapat menerima dan memberi saran atau bertanya tanpa batasan lokasi, waktu, dan tempat. Selain itu juga dapat meningkatkan kualitas proses pembelajaran baik dari sisi pengajar maupun siswa, hal ini terjadi karena informasi dapat diperoleh secara lebih luas dan tidak terbatas.

\section{METODOLOGI PENELITIAN}

Kegiatan ini menggunakan metode deskriptif kualitatif[2]. Percobaan yang dilakukan untuk mengumpulkan data pada penelitian ini adalah dengan melakukan uji coba e-learning. Pada mata pembelajaran dilakukan pengamatan secara langsung untuk melihat aktivitas siswa pada penggunaan e-learning[3]. Dilanjutkan dengan interview kepada setiap siswa dan pengajar mengenai metode pembelajaran menggunakan e-learning[4]. Setelah data terkumpul. Survey dilakukan melalui sistem kuesioner untuk melihat respon siswa mengenai metode pembelajaran berbasis web atau e-learning. 


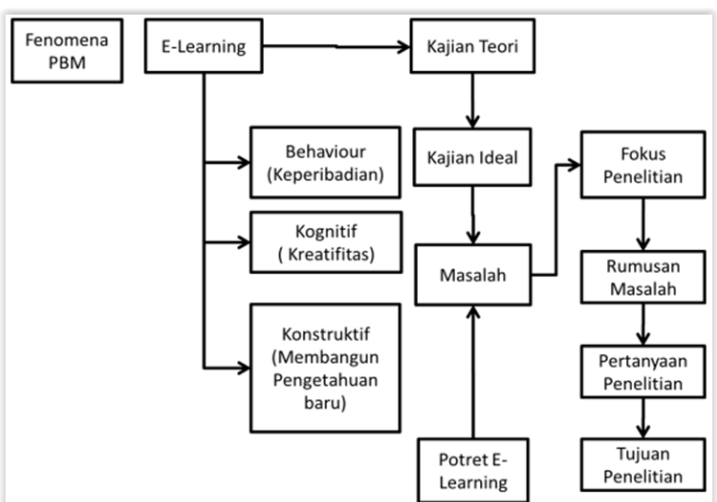

Gambar 1. Konsep Pemikiran Pembelajaran

Proses untuk menguji keabsahan data kualitatif adalah dengan cara menganalisi data secara berulang lalu melakukan reduksi data yang dilanjutkan dengan menarik kesimpulan dengan data yang ada[5]. Dengan begini akan diketahui bahwa metode pembelajaran secara terpusat atau secara digital yang lebih menguntungkan siswa dan pengajar.

\section{HASIL DAN PEMBAHASAN}

Yang terjadi dalam metode pembelajaran digital adalah siswa dapat dengan mudah memperolaeh materi pembelajaran tanpa batasan waktu. Menguntungkan bagi siswa yang absen pada hari itu. Pengajar juga dapat membahas materi pembelajaran e-learning didalam kelas. Dalam LCMS Moodle terdapat wadah untuk berinteraksi antara siswa atau pengajar dan siswa yang bersifat fleksibel yaitu Forum diskusi, forum ini berguna sebagai wadah untuk berkomunikasi dan berinteraksi mengenai pembahasan materi pemebelajaran antar siswa dan pengajar. Dalam forum ini semua partisipan bisa memberikan tanggapan opini dalam penilaian subjektif ataupun objektif. LCMS Moodle juga compatible untuk file dengan format PDF, XLS, DOC, ODT, dan sebagainya[6]. Pengajar pun bisa mempunyai akun penyimpanan data berbasis cloud antara lai Dropbox, Google drive, dan sebagainya.

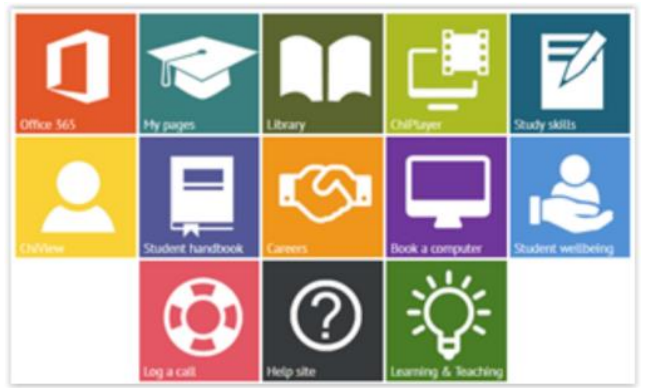

Gambar 2. Moodle Support[7]

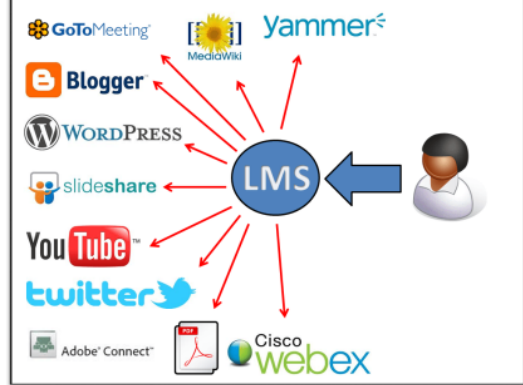

Gambar 3. Moodle Interactiv (LMS Moodle) 
Fitur Message, seperti pesan singkat pada aplikasi web lainnya. Pemberitahuan pesan masuk akan muncul sehingga pengajar akan menerima pesan tersebut. Upload Data, penguploadan data digunakan pada pengumpulan tugas. Fitur ini juga memiliki sistem batas waktu dan penentuan nilai bagi siswa dalam tugas pembelajaran mereka. Siswa tidak bisa mengupload data tugas pembelajaran mereka jika siswa tersebut menguploadnya melebihi batas yang pengajar berikan. Terdapat kolom teks yang bisa digunakan oleh pengajar untuk memberikan evaluasi terhadap tugas yang diberikan oleh siswa, evalusi tersebut dapat pula direspon oleh siswa yang nantinya dapat dijadikan bahan evaluasi pembelajaran secara sebjektif oleh siswa tersebut. Kuis Online, seperti sistem pada penguploadan data. Kegiatan kuis online juga dapat diatur oleh pengajar untuk waktu dan tanggalnya. Durasi pun ditetapkan sesuai peraturan yang diberikan oleh pengajar seperti 25 soal dalam waktu 30 menit. Kendala pada sistem kuis online ini terdapat pada jaringan internet. Kuis online ini sangat bergantung pada jaringan internet atau intranet yang ada. Access point ataupun LAN juga harus tersedia didalam ruang pembelajaran jika kuis online ini akan dilaksanakan didalam ruang pembelajaran. Peningkatan Kualitas pengajar, peningkatan kemampuan dan mengekplorasi pengetahuan baru akan diperoleh oleh pengajar dan proses pembelajaran dapat tercapai sesuai dengan rancangan kegiatan belajar mengajar tanpa batas ruang dan waktu.

Tabel 1. Entities User Moodle.

\begin{tabular}{|c|l|l|}
\hline No. & \multicolumn{1}{|c|}{ Data } & \multicolumn{1}{c|}{ Information } \\
\hline 1. & Lecturer & List of lecturers using the application \\
\hline 2. & Teaching Class & List of learning classes running \\
\hline 3. & College Student & List of registered students \\
\hline 4. & Study Card & List of lessons that are being undertaken by students \\
\hline 5. & Courses & List of courses at a college \\
\hline 6. & $\begin{array}{l}\text { Lecturer } \\
\text { Coordinator }\end{array}$ & List of coordinators on a lesson \\
\hline 7. & Material & List of E-learning materials in a class \\
\hline 8. & Task & List of class assignments on a lesson \\
\hline 9. & Forum & List of discussion forums from each class \\
\hline
\end{tabular}

Manfaat yang dirasakan oleh siswa pada kegiatan pembelajaran menggunkan e-learning yaitu berjalannya interaksi antara pengajar dan siswa dengan baik, siswa selalu tepat waktu dalam pengumpulan tugas dan dalam mengikuti kelas, dan membahas materi pembelajaran dengan diskusi. Pemanfaatan e-learning sendiri didalam sekolah berjalan dengan kondisi yang baik dengan persentase sekitar $60 \%$ dan karakteristik metode pembelajaran e-learning ini akan terus di kembangkan semaksimal mungkin. 


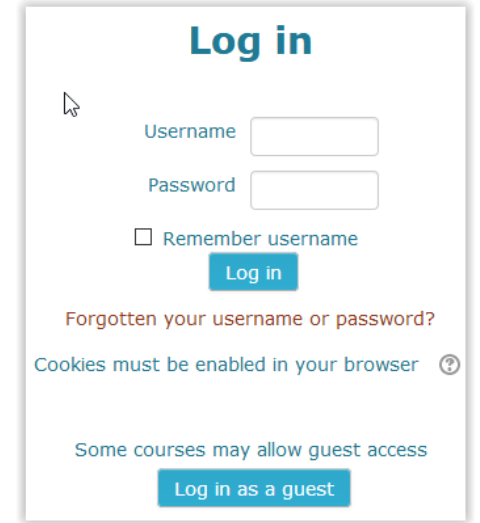

Gambar 4. Login Moodle Interactiv

\begin{tabular}{|c|c|}
\hline 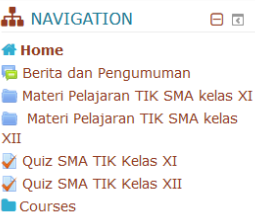 & $\begin{array}{l}\text { Mencoba Yang Terbaik } \\
\text { Mater Pelajaran TIK SMA kelas XI } \\
\text { Materi Pelajaran TKK SMA kelas XII } \\
\text { Quiz SMA TIK Kelas XI } \\
\text { Quiz SMA TIK Kelas XII }\end{array}$ \\
\hline
\end{tabular}

Gambar 5. Moodle Learn, Course, Quiz and News

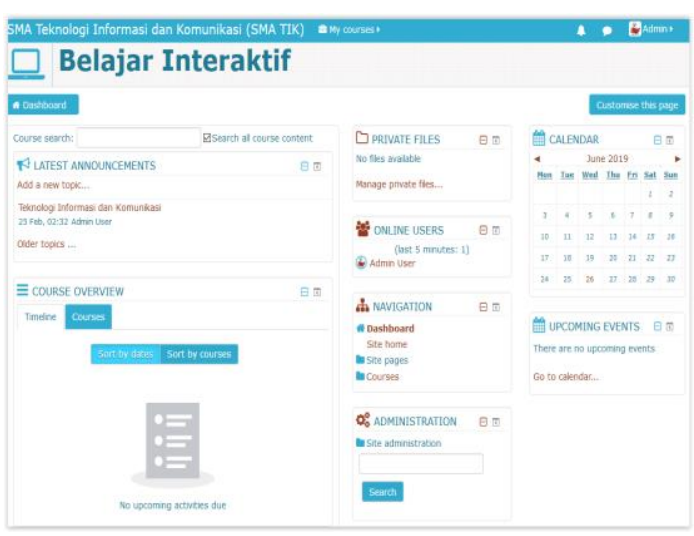

Gambar 6. Halaman Admin

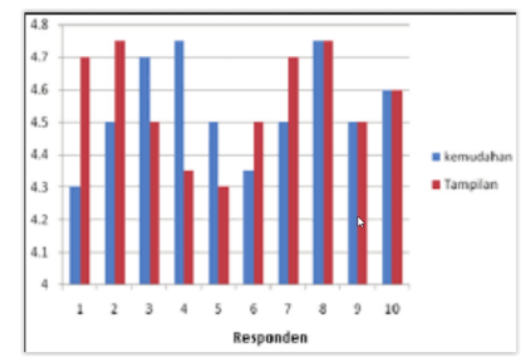

Gambar 7. Survei Penggunaan

Kemudahan dan Display Moodle terhadap Guru dan Siswa

E-learning diterapkan guna sebagai media pembelajaran. E-learning merupakan sesuatu yang baru bagi siswa, sehingga siswa selalu aktif dan kreatif dalam proses pembelajaran e-learning. Kreativitas siswa itu sendiri muncul pada saat siswa tersebut mengikuti kegiatan belajar mengajar. Namun kenyataannya elearning sendiri memiliki kelemahan. Kendala yang dirasakan oleh siswa dalam proses pembelajaran e-learning yaitu perangkat komputer dan internet yang tidak mendukung atau memadai pada saat pengumpulan tugas. Alternatif lainnya siswa menggunakan smartphone mereka untuk mengumpulkan tugas. Namun smartphone sendiri memiliki keterbatasan fasilitas, seperti compress, aplikasi pendukung lainnya dalam pembuatan bagan flowchart dalam membuat materi pembelajaran kecuali jaringan internet itu sendiri.

Dalam meningkatkan minat dan kreativitas siswa dalam metode pembelajaran e-learning itu sendiri adalah dengan melalui homepage. Kreativitas siswa dengan pembelajaran homepage merupakan hubungan yang positif. Melalui homepage pula media pembelajaran dan minat siswa sangat erat kaitannya. Karena e-learning merupakan hal baru bagi siswa dimana e-learning bisa dijadikan wadah untuk menggali kreativitas siswa. Terutama dalam sistem perkembangan elearning itu sendiri pada sistem pembelajaran didalam kelas.

Pemanfaatan e-learning dapat membangun komunikasi antara pengajar dengan siswa. Materi pembelajaran yang disajikan dengan e-learning dapat dipahami dan diterima dengan mudah oleh siswa kapan pun dan dimana pun sehingga dalam mengerjakan tugas tidak mengalami kendala. Message atau pesan 
singkat yang terdapat pada sistem pembelajaran e-learning dapat digunakan untuk diskusi dan berinteraksi dengan pengajar dalam membahas materi pembelajaran pada mata pelajaran tersebut. Perkembangan dalam penerapan metode e-learning masih berjalan lambat. Karena kendala yang dialami oleh partisipan yang mengambangkan sistem ini terdapat pada siswa dan pengajar itu sendiri. Mereka masih menganggap bahwa e-learning belum benar-benar dibutuhkan dalam proses pembelajaran. Begitu juga dengan fasilitas yang menunjang dalam perkembangan e-learning itu sendiri. Butuh biaya, tenaga, dan waktu yang cukup banyak untuk beberapa sekolah dalam menerapkan sistem pembelajaran elearning itu sendiri. Sedangkan dalam pembelajaran konvensional atau terpusat tidak begitu memerlukan biaya dan waktu yang banyak dalam penerapannya. Karena fasilitas dalam pembelajartan konvensional sudah terpenuhi, bahkan mungkin jauh sebelum sekolah tersebut didirikan. Namun e-learning merupakan prosesn pembelajaran yang penerapannya harus terus ditingkatkan.

Dalam penerapannya e-learning dapat dilakukan dengan 2 cara yaitu secara tatap muka dan dapat dilakukan secara online. Teori yang menjelaskan tentang pemanfaatan e-learning dapat digunakan dengan sistem kombinasi antara pembelajaran konvensional dan pembelajaran online berbasis web pada mata pembelajaran. Sebagian besar mata pelajaran akan lebih baik jika pembelajarannya melalui metode pembelajaran e-learning.

\section{KESIMPULAN}

E-learning berbasis LCMS Moodle bermanfaat sebagai media pembelajaran pada mata pelajaran karena dalam proses pembelajarannya yang lebih efisien dan efektif dalam segi waktu dan biaya. Karena metode pembelajaran e-learning sendiri tidak terbatas pada ruang dan waktu. Sehingga memudahkan siswa dalam menerima materi pembelajaran dimana pun dan kapan pun. E-learning sendiri merupakan hal baru bagi setiap siswa sehingga bisa dijadikan wadah untuk diskusi dan berinteraksi antar siswa atau dengan pengajar serta orang tua untuk membahas materi pembelajaran dalam kegiatan pembelajaran itu sendiri. Evaluasi pembelajaran dapat dilaksanakan oleh pengajar untuk siswa lebih tepat waktu sehinggan dapat menjadi pedoman dalam evaluasi pembelajaran siswa. Perkembangan e-learning harus berfokus pada infrastruktur dalam sekolah itu sendiri baik seperti intranet ataupun internet untuk mendukung kegiatan pembelajaran berbasis e-learning sehingga dalam penerapannya tidak ada kendala dalam proses pembelajaran berbasis e-learning. Dorongan motivasi perlu dilakukan untuk mengoptimalkan kegiatan e-learning ini dengan menggunakan perangkat komputer seperti Laptop ataupun smartphone.

\section{DAFTAR PUSTAKA}

[1] O. Dodun et al., "Analysis of an E-learning Platform use by Means of the Axiomatic Design," Procedia CIRP, vol. 34, pp. 244-249, 2015.

[2] I. K. Suartama, "Kualitas Pembelajaran Pada Mata Kuliah Media," J. Pendidik. dan Pengajaran, vol. 43, no. 3, pp. 253-262, 2010.

[3] V. Balasubramanian and S. Margret Anouncia, "Learning style detection based on cognitive skills to support adaptive learning environment - A reinforcement approach," Ain Shams Eng. J., 2016. 
[4] P. Purnawarman, S. Susilawati, and W. Sundayana, "The use of Edmodo in teaching writing in a blended learning setting," Indones. J. Appl. Linguist., vol. 5, no. 2, p. 242, 2016.

[5] D. Zhang, L. Zhou, R. O. Briggs, and J. F. Nunamaker, "Instructional video in e-learning: Assessing the impact of interactive video on learning effectiveness," Inf. Manag., vol. 43, no. 1, pp. 15-27, 2006.

[6] A. Bajahzer, A. Al-ajlan, and H. Zedan, "Exercise Services for E-Learning in Higher Education With Open Source Software," IADIS Int. Conf., no. Berry 2005, pp. 51-59, 2008.

[7] F. Destiawati, H. Dhika, and J. Purnama, "Perbandingan Cloud Computing Microsoft Onedrive , Dropbox , dan Google drive,” vol. 12, no. 58, pp. 20-27, 2019. 